\title{
Transformation of university functions in the conditions of knowledge-digital economy
}

\author{
N. Vasetskaya \\ Peter the Great St. Petersburg \\ Polytechnic University \\ St. Petersburg, Russia \\ vno@spbstu.ru
}

\author{
V. Glukhov \\ Peter the Great St. Petersburg \\ Polytechnic University \\ St. Petersburg, Russia \\ vicerector.me@spbstu.ru
}

\begin{abstract}
The subject of the research is the university in the conditions of knowledge economy. The purpose of the article is to analyze and rethink the basic functions of the university, to identify new functions of the university in the conditions of formation of modern economy. The research of the content and innovative potential of knowledge-digital economy is carried out. It is shown that the activity of universities in the conditions of formation and development of knowledge-digital economy is accompanied by revision and renewal of its mission and functions.
\end{abstract}

Keywords - knowledge-based digital economy, university functions, higher education, integration of knowledge, knowledge transfer, knowledge generation, lifelong learning, competence, research.

\section{INTRODUCTION}

In the conditions of formation of the digital era of economic and social development there is a formation of new directions of economic growth and their progressive development, which directly depends on the development of information and communication technologies (ICT) and the use of information, knowledge and innovations, which become the foundation for the development of society and civilizations.

According to the forecasts of many Russian and international experts, the prospects for the development of our society will be connected with man, namely with information and knowledge he produces, distributes and uses, intellectual capital and growing competence of personnel [1-3]. The modern economy has been transformed into a knowledgedigital one, in which it becomes an intangible asset, allowing to increase the efficiency of production and ensure the growth of the economy. Transition to knowledge-digital is the most urgent problem for the whole world community and the most important goal on the way to the sixth technological mode, the basic directions of which are presented by such technologies as alternative energy; nanotechnologies; global telecommunication information networks; biotechnologies; cognitive technologies and artificial intelligence systems, etc.

The main factor in the formation of a new economy is the modernization of the higher education system as the basis for stimulating socio-economic growth [4-6]. The nation's education and professional training are the most important vital values of citizens, the basis of the country's progress, its political and economic stability. Modernization of the higher education system, which generates a significant update of its content and functions, involves the formation of a new model of the university, which reflects the features of the current stage of socio-economic development of the country and meets the challenges of knowledge economy.

During the last decades, the study of the model of the university functioning remains in the center of attention of the academic community. Changes in environmental factors give rise to new functions of universities and the education system as a whole [7]. Consideration of the essence, rethinking the goals and functions of the university, its formation as a social institution, which is transformed together with the change of socio-economic and cultural development of society, have been studied and widely represented in the works of many Russian and foreign scientists of the present and past [8-9].

New formats of universities with a certain set of functions appear: corporate universities, universities of innovative type, entrepreneurial universities, network and virtual universities [10-11]. The identification of their new functions contributes to the formation of relevant formats in accordance with the requirements of the modern era.

The purpose of this article is to analyze and rethink the functions of the university in the development of knowledgedigital economy. To achieve this goal, the following tasks were solved: the study of the content and innovation potential of knowledge-digital economy, analysis of the transformation of the basic functions of the university when changing the socio-economic paradigm, identification of new functions of the university.

The results of the research can be aimed at improving the organizational and functional structure of the university, and can also be used in practical management activities by heads of universities as a conceptual basis for the formation of development strategies.

\section{CONTENT OF KNOWLEDGE-DIGITAL ECONOMY}

The lack of developments explaining the methodological aspects of studying the phenomenon of "knowledge economy" leads to the use of a wide range of terms for this phenomenon. In particular, some researchers associate knowledge economy in their works with the system paradigm [12], information and communication (digital) technologies [13, 14], innovations [15], intellectual capital [16], etc.

The main criteria of economic models in the system of post-industrial development of society are presented in Table 1. They have in common the recognition of the priority of 
development and efficiency of human capital use, but as the main factor of production its different components (services, innovations, information, knowledge) are used.

\section{TABLE I. CRITERIA FOR COMPARING ECONOMIC MODELS IN THE SYSTEM OF POST-INDUSTRIAL DEVELOPMENT OF SOCIETY}

\begin{tabular}{|c|c|c|c|}
\hline $\begin{array}{l}\text { Criteria/econo } \\
\text { mic model }\end{array}$ & $\begin{array}{c}\text { Factor of } \\
\text { production }\end{array}$ & $\begin{array}{l}\text { Development } \\
\text { Factor }\end{array}$ & $\begin{array}{l}\text { Development } \\
\text { Concept }\end{array}$ \\
\hline $\begin{array}{l}\text { Service room } \\
\text { economy }\end{array}$ & services & $\begin{array}{l}\text { increase in the } \\
\text { share of services } \\
\text { (science and } \\
\text { education); } \\
\text { increase in the } \\
\text { number of } \\
\text { employees in the } \\
\text { service sector; } \\
\text { Automation of } \\
\text { production on a } \\
\text { scientific basis }\end{array}$ & $\begin{array}{l}\text { The scientific } \\
\text { and } \\
\text { technological } \\
\text { revolution }\end{array}$ \\
\hline $\begin{array}{l}\text { Information } \\
\text { economy }\end{array}$ & info & $\begin{array}{l}\text { ICT } \\
\text { development; } \\
\text { Internet } \\
\text { development; } \\
\text { Increasing the } \\
\text { speed of } \\
\text { transmission and } \\
\text { exchange of } \\
\text { information }\end{array}$ & $\begin{array}{l}\text { The concept of } \\
\text { "knowledge } \\
\text { management" is } \\
\text { a scientific and } \\
\text { technological } \\
\text { revolution }\end{array}$ \\
\hline $\begin{array}{l}\text { Innovative } \\
\text { economy }\end{array}$ & innovations & $\begin{array}{l}\text { innovation; } \\
\text { emergence of } \\
\text { new goods and } \\
\text { services; } \\
\text { Growth of R\&D } \\
\text { expenditures; } \\
\text { Networking } \\
\text { expansion; } \\
\text { nanobiotechnolo } \\
\text { gy }\end{array}$ & $\begin{array}{l}\text { The concept of } \\
\text { "self-learning } \\
\text { organization" } \\
\text { information and } \\
\text { knowledge } \\
\text { revolution }\end{array}$ \\
\hline $\begin{array}{l}\text { Knowledge of } \\
\text { the digital } \\
\text { economy }\end{array}$ & knowledge & $\begin{array}{l}\text { knowledge and } \\
\text { intellectual } \\
\text { capital; } \\
\text { digital business } \\
\text { models; } \\
\text { development of } \\
\text { Big Data and } \\
\text { Data Science } \\
\text { technologies; } \\
\text { artificial } \\
\text { intelligence; } \\
\text { neurotechnologie } \\
\text { s }\end{array}$ & $\begin{array}{l}\text { Industry } 4.0 \\
\text { concept The } \\
\text { knowledge- } \\
\text { digital revolution }\end{array}$ \\
\hline
\end{tabular}

Summarizing different approaches, we can conclude that the knowledge-digital economy should be considered in a systematic and comprehensive manner. It can be characterized as, first, a service economy, as it tends to increase revenues from services in total national production and dominate production as a percentage; second, an information economy, in which information plays a dominant role as a factor of production and the development of information and communication technologies allows for the creation of new infrastructure for the processing and transmission of information flows; third, an innovation economy, as the source of The rapid development of digital technologies at the end of the 20th century led to the mutual diffusion of economic models and the fusion of their individual elements. Independent development of innovations, information and knowledge is not possible at present.
In general, within the framework of the present research the authors understand the system of social and economic relations of innovative-digital type based on the priority of intellectual human capital, intensive development of digital technologies, high-tech industries, and continuous professional education as the knowledge-digital economy.

\section{SCIENTIFIC-TECHNOLOGICAL AND INNOVATION POTENTIAL OF THE KNOWLEDGE-DIGITAL ECONOMY}

The development of the new economy is inseparable from high-tech and knowledge-intensive industries, which are based on nano- and biotechnologies, electronics, robotics and energy efficiency. Renewable energy sources, ICT. These industries are becoming a driving force for productivity, making basic technologies knowledge-intensive. In recent years, the role of science, high quality research and development, and knowledge-intensive technologies in the global economy has increased. Thus, according to the Industrial Research Institute (IRI), in 2018, the world's research and development expenditures amounted to $\$ 2172.1$ billion, of which about $60 \%$ was spent in three countries - the United States, China and Japan [17]. As in 2017 [18], Russia ranked 8th in this list, its share in global R\&D expenditure was $2.85 \%$ or $\$ 61.83 \mathrm{bn}$, and it changed insignificantly from the previous year (Fig. 1). According to forecast estimates, R\&D costs in Russia in 2019 will increase by $\$ 0.11$ billion and amount to $\$ 61.94$ billion.

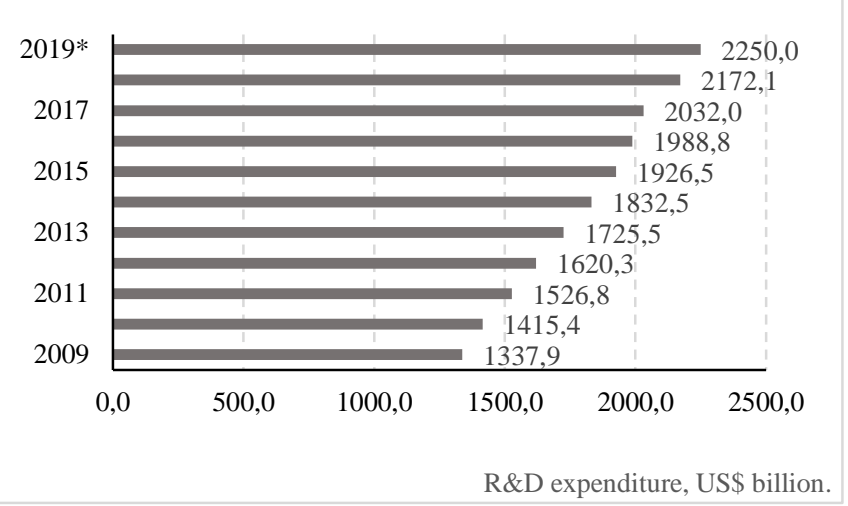

Fig. 1. Global research and development expenditure in 2009-2019, US\$ billion (* - for 2019 the forecast figures are presented)

According to Rosstat [19], the share of high-tech and knowledge-intensive products in Russia's GDP has an oscillatory dynamics, but at the same time, although insignificantly, the share of research and development costs in GDP increases (Table 2).

TABLE II. KEY INDICATORS OF HIGH-TECH AND KNOWLEDGE-INTENSIVE INDUSTRIES IN RUSSIA FOR 2011-2018,

\begin{tabular}{|c|c|c|}
\hline Year & $\begin{array}{c}\text { Share of high-tech and high- } \\
\text { tech products in GDP, \% }\end{array}$ & $\begin{array}{c}\text { Share of research } \\
\text { and development } \\
\text { costs in GDP, \% }\end{array}$ \\
\hline 2011 & 19,7 & 1,01 \\
\hline 2012 & 20,3 & 1,03 \\
\hline 2013 & 21,1 & 1,03 \\
\hline
\end{tabular}




\begin{tabular}{|c|c|c|}
2014 & 21,8 & 1,07 \\
\hline 2015 & 21,3 & 1,1 \\
\hline 2016 & 21,6 & 1,1 \\
\hline 2017 & 21,7 & 1,11 \\
\hline 2018 & 21,3 & - \\
\hline
\end{tabular}

In 2017, the structure of internal expenditures on research and development priorities in the development of science, technology and technology are life sciences (32.4\%), energy efficiency, energy conservation, energy conservation and nuclear power $(27.5 \%)$, transport and space systems $(15.1 \%)$ [19].

In 2017, two thirds $(66.2 \%)$ of research and development costs were financed by the state. The higher education sector is an intensively developing segment of Russian science: it is characterized by rather high annual growth rates. Thus, the average annual growth rate in this sector over the period of 2000-2017 was $8.4 \%$ and was higher than in other sectors: public $-5.5 \%$, business $-3.1 \%$. Overall, over the period 2000 2017 , the share of financing in the total amount of research and development costs in the public sector (from $54.4 \%$ to $66.2 \%$ ) and in the higher education sector (from $0.27 \%$ to $0.78 \%$ ) increased. The share of the entrepreneurial sector has decreased from $32.9 \%$ to $30.2 \%$ over the years [19].

However, in many developed and fast-growing countries, on the contrary, this source is considered the main one. Thus, in the U.S. it accounts for $64.2 \%$ of research and development costs, in Germany - $65.6 \%$, South Korea - 74.5\%, China $74.7 \%$, Japan - 78\% [20].

Thus, one of the problems of Russia's development is the weak activity of the entrepreneurial sector, which significantly distinguishes it from other developed world economies. Entrepreneurial sector organizations are one of the stakeholders in the results of scientific research and development, therefore, it is necessary to actively involve large business structures in the financing of innovations in order to transform the latter into competitive and popular developments, technologies and inventions. The development of small innovative business, which forms the basis of innovative ideas in developed countries, is of great importance. Practical implementation of commercially attractive ideas is possible in the process of integrating science and innovative entrepreneurship, for example, on the basis of universities.

In this regard, the issue of transformation of higher education organizations, namely universities, which differ in the presence of integration of educational, cognitive and research and production activities, becomes particularly relevant. In the digital knowledge economy, universities themselves are becoming the most important actors in the production of ideas, knowledge and technologies, as well as important consumers of skilled personnel.

\section{UNIVERSITY AND ITS FUNCTIONS IN THE KNOWLEDGE-DIGITAL ECONOMY}

In the process of changing the socio-economic phase (preindustrial, industrial, post-industrial society), the content of the university and its functions were reviewed and supplemented.

In pre-industrial society, the university was born as a "circle" uniting people with common views, as a form of self- organization of intellectuals. The first universities created a basic structure for the process of knowledge preservation and transfer through education. The university science was similar, existed separately from production and had no applied basis. In an industrial society caused by the industrial revolution, the developing industry demanded a sharp increase in knowledge, especially in the natural sciences. In university science there appeared an independent sphere - the research activity, the purpose of which was to turn fundamental research into practical one with their subsequent implementation into production. A new function of the university is the generation of knowledge. The basis of the post-industrial society was the information revolution, as a result of which the indicator of the success of the country's development is the formation of the market of services and the information sector. The University is becoming the main supplier of highly qualified personnel for industry and business. The penetration of market relations into the sphere of science has led to the fact that in addition to the basic functions that have been formed in pre-industrial and postindustrial society, there is another one - the commercialization of knowledge.

Consideration of the essence, reconsideration of the goals and functions of the university, its formation as a social institution, which is transformed together with the change of socio-economic and cultural development of the society, has been studied and widely represented in the works of many Russian and foreign scientists of the present and past.

However, representatives of various scientific directions have formed significant differences in the content of the university idea. Conceptual approaches to the classification of functions of higher education have a narrow focus and differ significantly. The main focus of the research is on basic functions, such as educational (training), research, educational, social and educational functions.

The works of modern researchers also do not take into account the specifics of universities' activities in the context of a change in economic paradigm. In this connection, the list of the abovementioned basic functions of the university should be reconsidered and supplemented with fundamentally new functions

In the conditions of knowledge-digital economy, which differs from the previous socio-economic models by such specific features as the development of education, science and technology, the processes of their integration and commercialization, intellectualization of labor, internationalization and globalization, the development of network structures and information and communication technologies, the process of modernization of higher education has significantly changed its essence and content, adapting them to the realities of modern economics. Classification of university functions in the conditions of formation of knowledge-digital economy is presented in table 3. 
TABLE III. CLASSIFICATION OF UNIVERSITY FUNCTIONS IN THE CONDITIONS OF FORMATION OF KNOWLEDGE-DIGITAL ECONOMY

\begin{tabular}{|c|c|c|}
\hline \multirow{7}{*}{$\begin{array}{l}\text { Functions of } \\
\text { the university }\end{array}$} & \multirow{4}{*}{ Basic functions } & $\begin{array}{l}\text { Educational } \\
\text { (training) }\end{array}$ \\
\hline & & $\begin{array}{l}\text { Research and } \\
\text { development } \\
\text { (knowledge } \\
\text { generation) }\end{array}$ \\
\hline & & Educating \\
\hline & & Social \\
\hline & \multirow{3}{*}{ New features } & $\begin{array}{l}\text { Knowledge } \\
\text { Transfer }\end{array}$ \\
\hline & & $\begin{array}{l}\text { Knowledge } \\
\text { integrator }\end{array}$ \\
\hline & & $\begin{array}{l}\text { Function of mass } \\
\text { formation } \\
\text { competencies }\end{array}$ \\
\hline
\end{tabular}

The basic functions of the university are represented by educational, research, educational and social functions, which have been transformed and changed in terms of importance in the modern economy.

As the knowledge economy develops and matures, the demands on the education system as a whole increase significantly, and the education institute becomes a key factor in the economic and social development of society. The knowledge economy requires extensive education and training systems that cover an ever-growing segment of the population and ensure the growth of the share of highly qualified specialists. The educational function of the university is becoming more and more important and in the new economy it is taking on the features of continuous education, within the framework of which systematic training and retraining of personnel on the type of "life-long learning" is expected.

"Lifelong learning" implies the expansion of learning opportunities for citizens regardless of age, qualification and level of education. The life-long learning system covers all forms of education (formal, non-formal, informal) and knowledge acquisition at all stages of life - from preuniversity to postgraduate education and professional development programs.

The implementation of the concept of "lifelong learning" requires a review of the teaching methods at universities, which are designed to ensure the creation of flexible personal educational trajectories that provide an opportunity to continue learning and change educational orientation. Within the framework of the new educational paradigm, the interaction between all subjects of education, labour market and production sphere is being strengthened. The educational function of the university, which has been basic since preindustrial society, acquires new features and assumes a process of education, which is carried out on a continuous basis in order to improve knowledge, skills and competencies necessary for personal and social development and employment.

The most important basic function of the university remains the research function, which forms the intellectual culture of students, namely their personal and professional qualities, such as the desire for creative realization, systematic thinking, application of knowledge in solving problems. It is planned to conduct scientific research relevant for the global scientific and educational community, and the teacher acts before the student in a new role - scientist, researcher and mentor.

In the conditions of the new economy, the central pillar of which is scientific research and technology, the role of the research function of the university increases significantly. Fundamental scientific research, as the basis of tomorrow's technologies, should be given special attention.

The educational function of the university, which forms the culture in the society, and the students have high moral qualities and universal values, is closely connected with the social function. However, it should be noted that as a result of social and economic transformations, these functions are relegated to the background and are of secondary importance.

Renewal of the functions of the university occurred in the conditions of the change of social and economic paradigm, when higher education becomes relevant, forming the ability not only to apply the acquired knowledge, but also to create new knowledge and act in accordance with it [21].

Knowledge society requires not only a much faster use of new knowledge and achievements in science in practice, but also generates technologies that accelerate this process, which creates new prerequisites for interaction between universities and high-tech enterprises of the real sector of the economy. Therefore, as a result of university-enterprise cooperation, a fundamentally new function of the university "knowledge transfer" is created, which is directly related to the innovative activity of the organization. This function of the university includes two main processes: commercialization of research results and implementation of market-oriented educational programs.

The knowledge transfer aims to ensure the transfer of knowledge, including technology, experience and skills, from the university to external customers - enterprises, public and state structures, leading to innovation in the economy and public sphere. In terms of terminology, it is worth noting that the more familiar concept of "technology transfer", which characterizes the organizational process of transfer of scientific and technological know-how from the scientific laboratory to production in a market economy, is replaced by the more capacious term "knowledge transfer". The analogue of this concept in the planned system of national economy was the term "introduction of inventions".

The function of "knowledge transfer" associated with the commercialization of the results of scientific research activities may include the organization of scientific research within the framework of economic contracts with organizations and enterprises, the use and transfer of intellectual property rights within the framework of licensing agreements, participation in federal and regional development programs, and the creation of innovative infrastructure of the university. The second main process of knowledge transfer is related to the development and implementation of innovative educational programs, which are in demand in the labor market and allow enterprises to obtain personnel with the necessary professional qualities and competences from their implementation.

It is necessary to emphasize the importance of the "knowledge transfer" function in the conditions of globalization and internalization of the world community and the possibility of its consideration as an independent direction 
of the university's activity in the context of international technology transfer and education export. This is a traditional function for leading international universities, but it is a new function for Russia.

Another new function of the university in the modern economy, which can be regarded as fundamental, is related to the function of "knowledge transfer" - the function of "knowledge integrator". An "integrator" is an organization that implements the processes of interaction between the components of a complex system, namely, the processes of generation, exchange and transfer of knowledge.

One of the specific features of the knowledge economy is the intellectualization of labor due to the increasing value of inventive, creative and highly intellectual specialists, the appearance in the labor activity of a large number of tasks with a "blurred" interdisciplinary structure, requiring nonstandard innovative approaches and solutions in various aspects of professional activity. Research institutes, high-tech companies, industrial corporations, government agencies also generate new knowledge, but the center of reproduction of the intellectual potential of society is the university.

The University acts as an intermediary for cooperation of educational and scientific structures with industry, business and state authorities in order to solve interdisciplinary scientific problems. In the process of performing the functions of knowledge integrator, the university not only provides its own potential for use by other participants of organizational interaction, but also on the basis of its intellectual resources provides an opportunity for the exchange of knowledge and intellectual capabilities of the participants of partnership interaction between themselves, that is, acts as a catalyst for interaction.

As a result of integration processes in the structure of universities, new innovation-integrated structures are being created in the form of research laboratories, basic departments, joint laboratories, incubators, technoparks, technology transfer centers, the purpose of which is the commercialization of scientific achievements, their practical implementation and creation of high-tech competitive products in the Russian and international markets [22].

The Federal Law of August 2, 2009 No. 217-FZ "On Amendments to Certain Legislative Acts of the Russian Federation on the Creation of Business Entities by Budget Scientific and Educational Institutions for the Purpose of Practical Application (Introduction) of the Results of Intellectual Activity" [23] gives the right to universities and scientific organizations to create a belt of small innovative enterprises (SIE), within the framework of which teachers and students could gain practical experience of real business activity.

One of the specific features of the knowledge economy is the development of network structures as important agents of dissemination and implementation of new scientific knowledge and development of strategic know-how and professional competences. The development of modern information and communication technologies allows the participants of one group to work on the solution of scientific and technical problems, being in different locations without time limits. In this regard, universities are developing the function of mass formation of competencies, which acquires the most important importance as a result of the massization of higher education and the high importance of the intellectual component within the production processes. These competences include research, project, managerial and other professional competences, which allow mass inclusion of people in cognitive activity. This allows organizing the participation in the production of knowledge and innovations of a wide range of people, not as scientists and inventors, but as specialists within the framework of quality management systems of products and services, customer relationship management systems, business process re-engineering, etc.

\section{CONCLUSION}

Thus, the change of social and economic paradigm, the processes of globalization and internalization, the formation of knowledge-digital economy put forward new requirements for higher education and make universities responsible for the formation of the ability not only to create new ideas, knowledge and technologies, but also to transfer them to the production sector and use them in interaction with enterprises of the high-tech sector of the economy.

Universities act as a center of interrelation between public authorities and industry, transfer of knowledge, generator of new knowledge and technologies, as well as to determine the potential and strategy of state development, competitiveness of the national economy. Therefore, the training system should be aimed at training highly qualified innovative personnel.

On the basis of the conducted research of university functions the results were obtained, which allowed to develop the author's classification of university functions in the conditions of formation of knowledge economy by means of revision of basic functions and identification of new ones, which are of paramount importance for universities in modern society: the function of knowledge transfer, knowledge generator and function of mass formation of competences.

\section{REFERENCES}

[1] Parushina N.V., Lytneva N.A., Semidelikhin E.A. Methods of measuring and evaluating human capital // Scientific review. Economic sciences. 2017. № 2. C. 89-99

[2] Kofman E. The Knowledge Economy, Gender and Stratified Migrations // Studies in Social Justice. V. 1. Is. 2. 2007. P. 122 - 135.

[3] Vasetskaya N.O. Development of competencies of scientific and pedagogical staff of the university // Research azimuth: economics and management. 2018. T. 7. №3(24). C.61-64

[4] Solovyova L.V., Solovyova L.I. Education as a factor of social and economic development of Russia and regions // Scientific Vedomosti. 2016. №23 (244). C. 22-29

[5] R.E. Kesaeva, T.T. Biazrova, G.A. Kantemirova-Kanukova. 2014. № 9-6. C. $1339-1342$

[6] Mayorova S.V. Prospects of education development in Russia for 2018 // Education process. 2017. №2. C. 18-20

[7] Reznik G.A., Kurdova M.A. Functions of the Russian University in the conditions of formation of innovation-oriented economy // Integration of education. 2017. T.21 №3. C. 441-457

[8] V.S. Efimov, A.V. Lapteva, Cognitive University: contours of the future // Strategic guidelines. 2014. №6. C. 18-29

[9] Bogdanovich O.I., Merkulov A.S., Ruposov V.L. The role of universities in the development of economy // Vestnik Permskogo universiteta. 2015. Issue. 2(25). C. 15-21

[10] A. Karpov Modern University as a Driver of Economic Growth: Models and Missions // Economics. 2017. № 3. C. 58-76. 
[11] Machlup F. Knowledge: Its creation, distribution and economic significance. 2014. Vol. I: Knowledge and knowledge production. Princeton: Princeton University Press.

[12] Kleiner G.B. Economics. Modeling. Mathematics. Selected works. M. TZEMI WOUNDS, 2016

[13] Slavin B.B. Interrelation of stages of development of information technologies and economy // Information society, 2015. № 6. C. 4-13.

[14] Slavin B.B. From computational to human-oriented IS // Modern information technologies and IT education, 2017. № 3. C. 176-184.

[15] Borbugulov M.U. Knowledge Economy - the basis of innovative economics // Vestnik Kyrgyz-Russian Slavic University, 2015. № 3. C. 14-16

[16] Panikarova S.V., Vlasov M.V. Knowledge and Intellectual Capital Management: A Manual. M.: Yurayt Publishing House. 2019. 142 c.

[17] 2018 Global R\&D Funding Forecast. Digital. [Electronic resource]. URL: http://digital. rdmag.com/researchanddevelopment/2018_global_r_d_funding_forec ast?pg=1\#pg1.

[18] 2017 Global R\&D Funding Forecast. Digital. [Electronic resource] URL: http://digital rdmag.com/researchanddevelopment/2017_global_r_d_funding_forec ast\#pg1.

[19] Statistical collection / N.V. Gorodnikova, L.M. Gohberg, K.A Ditkovsky et al.; National Research University "Higher School of Economics". Moscow: National Research University Higher School of Economics. 2018. 320 c.

[20] HSE: Russian Federation's research and development costs reached 943.8 billion rubles in 2016. News. [Electronic resource]. URL: https://news.rambler.ru/business/38323205/?utm

content=rnews\&utm_medium=read_more\&utm_source=copylink.

[21] Reznik G.A., Kurdova M.A. Functions of the Russian University in the conditions of formation of innovation-oriented economy // Integration of education. 2017. T.21 №3. C. 441-457

[22] Vasetskaya N.O., Klochkov Y.S. Integrated innovative scientific and educational structures as a tool for training of professional staff in the field of engineering and technical education. Saint-Petersburg: BMW \& K LLC, 2017. 159c.

[23] On Amendments to Certain Legislative Acts of the Russian Federation Concerning the Creation of Business Entities by Budget Scientific and Educational Institutions for the Purpose of Practical Application (Introduction) of the Results of Intellectual Activity: Federal Law No. 217-F of August 2, 2009. 